\title{
Drought tolerance of three ethnomedicinal shrubs evaluated based on their seed germination rates at different drought levels induced by using polyethylene glycol ( PEG $\left._{6000}\right)$
}

\author{
Mohammed Dadach $^{1 *}$, Zoheir Mehdadi ${ }^{2}$ \\ ${ }^{1}$ Laboratoire de Recherche en Ecologie et Environnement, Faculté des Sciences de la Nature et de la Vie, \\ Université de Bejaia, 06000, Bejaia, Algeria \\ ${ }^{2}$ Laboratory of Plant Biodiversity: Conservation and Valorization, Faculty of Natural Sciences and Life, \\ Djillali Liabes University, Sidi Bel Abbes, 22000, Algeria
}

\begin{abstract}
Dadach. M., Mehdadi, Z., 2021. Drought tolerance of three ethnomedicinal shrubs evaluated based on their seed germination rates at different drought levels induced by using polyethylene glycol $\left(\mathrm{PEG}_{6000}\right)$. Folia Oecologica, 48 (1): 49-54.

Sideritis incana, Stachys ocymastrum, and Thymus fontanesii are medicinal plants belonging to the Lamiaceae family and occurring in semi-arid lands in northern Algeria and in many other countries along the Mediterranean coastline. Despite the ecological and economic interests and also the questionable future these species may meet in their natural habitats, various aspects of their seed biology have not been recognised to this date. This study was intended for in situ conservation of these plants. The problem investigated was the germination response of seeds to different water potential levels attained with using different amounts of polyethylene glycol $\left(\mathrm{PEG}_{6000}\right)(0,-0.03,-0.07,-0.2,-0.5,-1$ and $-1.6 \mathrm{MPa})$. In this way, the appropriate conditions and the threshold tolerance of seed germination against water stress were assessed. Seeds of the three species lacked primary/innate dormancy and they germinated abundant and fast in distilled water $(S$. incana $-65 \%$; S. ocymastrum $-60 \%$ and $T$. fontanseii $-90 \%$ ). Small seeds of $T$. fontanesii tolerated more water stress and germinated under up to $-1 \mathrm{MPa}$ ( -10 bars). Large seeds of $S$. incana and $S$. ocymastrum, however, were more sensitive to the drought stress and germinated only under $-0.5 \mathrm{MPa}(-5$ bars $)$. Moreover, more studied parameters were found developing negative reponse under rising drought stress, such as postponed triggering of seed germination, decreased germination velocity and prolonged germination duration, as well as the average time of germination. Therefore, these three plants appear to postpone their establishment until arrival of conditions promising for germination, including sufficient rainfall.
\end{abstract}

Keywords

germination, Lamiaceae, polyethylene glycol, water stress

*Corresponding author:

e-mail: dadach_mohamed@yahoo.fr

(C) 2021 Authors. This is an open access article under the CC BY-NC-ND license (http://creativecommons.org/licenses/by-nc-nd/4.0/) 


\section{Introduction}

Covering almost $1.6 \%$ of the Earth's surface, the Mediterranean basin, with more than 25,000 (10\%) of the world's Spermaphytes, harbours a particular richness of plant diversity (MEDAIL and QUezel, 1997). A standardised sampling study leaded by FERNANDEZCALZADO et al. (2012) reports that some Mediterranean sites with prevalent rare and endemic plants have been designated as regional hotspots. In this region, however, some environmental constraints (i.e. drought and high salinity levels in soils) are considered to be the major factors limiting plant establishment and prosperity. Up to now, Mediterranean plant communities have been exhibiting either endurance or adaptation failures against erratic climate, with the changes in timing, synchronicity and amount of precipitation seeming unpredictable (Cochrane et al., 2015). For these reasons, the Mediterranean ecosystem was very attractive for researchers and naturalists, providing them with the possibilities to deepen their knowledge about the plant adaptation under the diversity of climatic scenarios, involving shortage in water availability.

The key problem in the plant stress research, is understanding of how this stress influences the plant behaviour and how the plants interact through their plasticity and adaptability (BLuM, 2015). On the other hand, plants thriving in unpredictable and variable environment may display various strategies developed to overcome harsh ecological conditions, from the first up to the last phase of their life cycle; and in this way these strategies ensure the plants successful establishment and long-term population survival. Indeed, tolerance of seeds against drought is usually dependent on the ability of seeds to germinate even under the lowest levels of water potentials induced by water shortage. As a part of plant conservation strategies, knowledge on seed germination tolerance against drought is the cornerstone for framing the post-germination behaviour leading to successful plant establishment (DoNOHUE et al., 2010).

It is worth noting that numerous studies had already exhibited the negative effects of water stress on germination success in various Mediterranean plants (GorAI et al., 2014; DADACH et al., 2015). Thus, germination failure under decreasing water potential is often due to the inactivated enzymes and hormones found in seeds. Furthermore, water stress may disrupt mechanisms leading to radicle protrusion, therefore the seed germination triggering is postponed (GILL et al., 2003). The processes used for controlled drought simulation at laboratory include treating seeds with polyethylene glycol (PEG), a nonionic water polymer restraining water percolation through the seed coat (PAVIA et al., 2019).

Sideritis incana, Stachys ocymastrum and Thymus fontanesii are three Lamiaceae mainly used in folk medicine, thanks to their multiple therapeutic effects (LAKHAL et al., 2011; Cheurfa et al., 2013). In this context, these tree species are actually suffering overexploitation, exaggerated by drought and soil salinity (UNDERWOOD et al., 2009). A previous study reports that mature seeds of these three species display a wide range of viability, with a characteristic non-deep primary dormancy (DADACH and MeHDADI, 2018a). There have already been recognised differences in salinity tolerance of these species, indicating that $\mathrm{NaCl}$ delayed and/or even potentially hampered the germination process at higher saline concentrations (DADACH et al., 2018). Neverheless, the effects of drought stress have not been investigated yet. The purpose of this study was to evaluate the germination performance of the studied species facing water stress, with the aim to provide research results for conservation programs targeted at the remaining populations in the Tessala Mount, Algeria.

\section{Materials and methods}

\section{Plant material}

Mature seeds of Sideritis incana $\left(35^{\circ} 16^{\prime} 23.54^{\prime \prime} \mathrm{N}\right.$, $0^{\circ} 46^{\prime} 45.01$ " W), Stachys ocymastrum $\left(35^{\circ} 16^{\prime} 03.94\right.$ " N, 0 46'18.63" W), and Thymus fontanesii (35'16'19.19' ' N, $00^{\circ} 46^{\prime} 02.14$ " W), ready to disperse (Fig. 1), were collected in the summer 2015 from a scrubland community growing in the Tessala Mount located in North-Western Algeria. This location is semi-arid with typical Mediterranean climate characteristics; with summer temperature occasionally exceeding $35^{\circ} \mathrm{C}$ and annual precipitation generally less than $400 \mathrm{~mm}$. The seeds were picked up randomly from the vast number of plants of each of the tested species (more than 30 for each). At the laboratory, seeds were immediately peeled manually from the inflorescence husk, their surface was sterilized with $5 \%$ of bleach (sodium hypochlorite) for $5 \mathrm{~min}$, then followed a thorough rinsing with distilled water and air-drying. The seeds were stored in bags under ambient laboratory temperature, until the implementation of the tests.

\section{Germination experiments}

Before the beginning of the experiments, the seeds were subject to a float test in water, to determine their viability; with the drowned seeds presumed as full and viable (CALOnJE et al., 2011). Thereafter, seeds from the different tested plants were set in a series of $\mathrm{PEG}_{6000}$ concentrations of $0,-0.03,-0.07,-0.2,-0.5$ and $-1 \mathrm{MPa},(-1.6 \mathrm{MPa}$ added for $T$. fontanesii). The seeds were arranged in $9 \mathrm{~cm}$ Petri dishes, split up into four replications per an assay $(n=4)$ of 25 seeds per a lot, placed on two layers of Whatman No. 1 filter paper and supplied with $10 \mathrm{ml}$ of PEG solution except for the control $(0 \mathrm{MPa})$, deionised water was used. The dishes were wrapped with a lid to minimize the evaporation and incubated at the optimum germination conditions for the three species, known to be $20{ }^{\circ} \mathrm{C}$ in darkness (DADACH and Mendadi, 2018a). The used PEG levels were selected based on the results of a preliminary experiment assessing drought tolerance in the three species. Germinated seeds (i.e. protrusion by embryonic axis) were recorded every two days up to the germination end. 


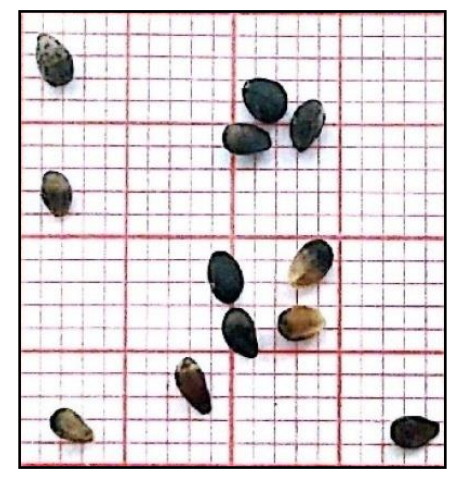

A

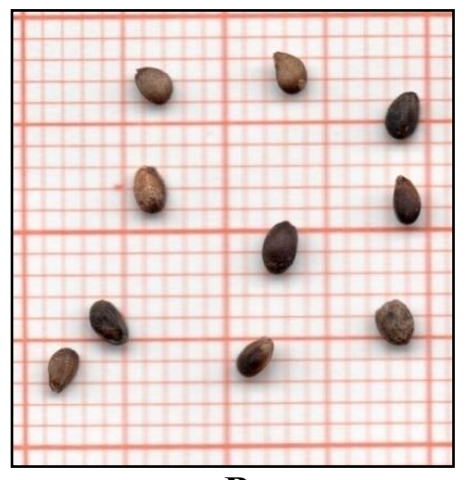

B

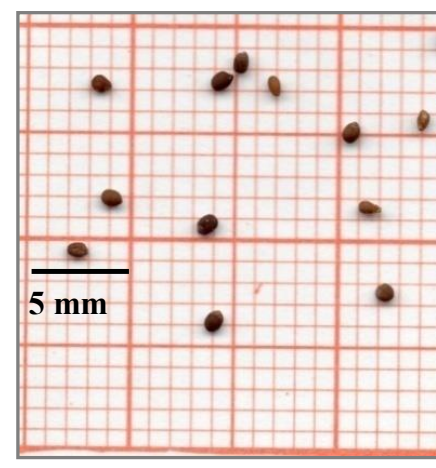

C

Fig. 1. Seeds of the three studied species. A, Sideritis incana; B, Stachys ocymastrum, C, Thymus fontanesii.

\section{Data analysis}

With the aim to better understand the germination performance, the following parameters were recorded: Germination percentage (GP), latency time or time taken by each lot to record the first germinated seeds (LT), germination length from the beginning until the end of germination (GL), germination velocity $(\mathrm{GV})$ expressed as $G V=\sum G_{i} / t$, where $G_{i}$ is percent germination at 2 days interval and $t$ is the total germination time (KHAN and UNNGAR, 1984), further, the mean time of germination (MTG), expressed as $M T G=\sum n_{i} t / N$, where $n_{i}$ is the number of seeds that had germinated at the day $i, t$ is the time from the start of the experiment to the $i$ th observation and $N$ is the total number of germinated seeds (RANAL and SANTANA, 2006).

The data were tabulated and analysed using SPSS for Windows, version 20. Germination data were arcsine transformed from the number of germinated seeds to percentages \pm standard error (SE), before the statistical analysis, to ensure the homogeneity of variance. A oneway analysis of variance (ANOVA) was carried out to test the effects of water stress on the main germination patterns. A paired-samples $t$-test, by using Tukey test, was conducted to estimate the least significant differences between the mean germination percentages.

\section{Results and discussion}

The applied stress affected significantly $(\mathrm{p}<0.05)$ the final germination percentage (GP) (see the results of analyse of variance (ANOVA), Table 1). As supposed, the germination maxima in Sideritis incana, Stachys ocymastrum and Thymus fontanesii were attained in absence of stress $(0 \mathrm{MPa})$. The seed germination decreased with increasing stress, and it stopped completely for $S$. incana and S. ocymastrum at $-1 \mathrm{MPa}$ and for T. fontanesii at $-1.6 \mathrm{MPa}$ (Fig. 2). These figures are considered as the germination threshold tolerance values. Similar results have already been given in several studies as ABBAD et al. (2011) and DADACH et al. (2015) reporting that the seeds of Thymus maroccanus, T. broussonetii and T. serpyllum were affected by the drop in water potential and, contrarily, they exhibited a high germination rate in the stress absence. Similarly, germination of Stipa tinacissima, grass flourishing in the Mediterranean semi-arid climate areas, was also very sensitive to a range of water potential from 0 to $-1.6 \mathrm{MPa}$ (KRICHEN et al., 2014). In fact, FAISAL et al. (2019) inferred that the effects of drought stress depend not only upon the intensity and length of water shortage but also upon the phase of plant growth, as the germination is the most sensitive stage in the plant life cycle, and as such, this stage is the most sensitive to stress.

The results summarised in Table 1 show that the water stress affected not only GP but that the rising water stress influenced significantly $(p<0.05)$ also the other germination parameters. In summary, the latency time (LT), germination length (GL) as well as average time of germination (MTG) showed the shortest values at the absence of stress. The seeds of $S$. ocymastrum and $T$. fontanesii germinated most quickly (LT $=2$ days), unlike the control $S$. incana seeds (LT $=7.4$ days). However, the LT was delayed when the water potential dropped. Regarding the germination length (GL), the control exhibited the shortest periods of germination ( $T$. fontanesii germination took less time at $-0.03 \mathrm{MPa}$ than at $0 \mathrm{MPa}$, but no statistically significant difference was recorded), contrarily, GL extended with increasing water stress. The mean time of germination (MTG) uniformly increased with decreasing water potentials in the studied three species, which means from 10.5 to 13.4 days for $S$. incana (despite no statistically significant difference among values), 5.8 up to 7.2 days for S. ocymastrum and 4.6 to 7.4 days for $T$. fontanesii. On the other hand, the germination velocity $(\mathrm{GV})$ dropped steeply with falling water potential (0 MPa, $17 \%$ vs $-0.5 \mathrm{MPa}, 1.2 \%$, S. incana); (0 MPa, $24 \%$ vs $-0.5 \mathrm{MPa}, 3.5 \%$, S. ocymastrum) and (0 MPa, 38.1\% vs $-1 \mathrm{MPa}, 14.8 \%, T$. fontanesii). A remarkable delay in germination with the decrease in water potential was observed also by other authors (AL-TAISAN et al., 2010; DADACH and MehDAdi, 2018b; PAVIA et al., 2019).

Seed germination in $S$. incana, $S$. ocymastrum and $T$. fontanesii, under the Mediterranean climate conditions, sets out in late autumn, when precipitation often onsets (GALméset al., 2006). Consequently, regarding the lacking precipitation in the late summer and early autumn, the 
Table 1. Germination parameters of $S$. incana, S. ocymastrum and T. fontaneseii seeds, incubated at $20{ }^{\circ} \mathrm{C}$, in response to water stress (mean $\pm \mathrm{SE}, \mathrm{n}=4$ ). Germination percentage (GP, \%); latency time (LT, days), germination length (GL, days); germination velocity $(\mathrm{GV}, \%)$; mean time of germination (MTG, days)

\begin{tabular}{|c|c|c|c|c|c|}
\hline PEG (MPa) & GP (\%) & LT (days) & GL (days) & GV (\%) & MTG (days) \\
\hline \multicolumn{6}{|l|}{ Sideritis incana } \\
\hline 0 & $65 \pm 5^{a}$ & $7.4 \pm 1.2^{\mathrm{a}}$ & $14 \pm 0^{\mathrm{a}}$ & $17 \pm 1.5^{\mathrm{a}}$ & $10.5 \pm 0.2^{\mathrm{a}}$ \\
\hline-0.03 & $58 \pm 3^{b}$ & $8.6 \pm 1.2^{\mathrm{ab}}$ & $17.4 \pm 1.2^{\mathrm{b}}$ & $12.8 \pm 1.9^{\mathrm{ab}}$ & $12 \pm 0.9^{\mathrm{a}}$ \\
\hline-0.07 & $38 \pm 3^{c}$ & $9.4 \pm 1.6^{\mathrm{abc}}$ & $17.4 \pm 1.2^{\mathrm{b}}$ & $8.6 \pm 1.7^{\mathrm{bc}}$ & $13.1 \pm 1.1^{\mathrm{a}}$ \\
\hline-0.2 & $28 \pm 4^{\mathrm{d}}$ & $10 \pm 0^{\mathrm{bc}}$ & $16 \pm 0^{\mathrm{b}}$ & $6.4 \pm 1^{\mathrm{c}}$ & $13.4 \pm 1.6^{\mathrm{a}}$ \\
\hline-0.5 & $5 \pm 2^{\mathrm{e}}$ & $11 \pm 1.4^{\mathrm{c}}$ & $14.2 \pm 1.4^{\mathrm{a}}$ & $1.2 \pm 1.2^{\mathrm{d}}$ & $12.2 \pm 0.2^{\mathrm{a}}$ \\
\hline-1 & $0^{\mathrm{e}}$ & - & - & & - \\
\hline$F$ value & 172.20 & 4.43 & 12.12 & 46.89 & 1.56 \\
\hline \multicolumn{6}{|c|}{ Stachys ocymastrum } \\
\hline 0 & $60 \pm 8^{a}$ & $2 \pm 0^{\mathrm{a}}$ & $8.8 \pm 1.2^{\mathrm{a}}$ & $24 \pm 1^{\mathrm{a}}$ & $5.8 \pm 0.6^{\mathrm{ab}}$ \\
\hline-0.03 & $45 \pm 4^{b}$ & $2.6 \pm 0.8^{\mathrm{a}}$ & $9.4 \pm 0.8^{\mathrm{a}}$ & $18.1 \pm 2.4^{b}$ & $5.5 \pm 0.8^{\mathrm{ab}}$ \\
\hline-0.07 & $30 \pm 5^{c}$ & $2.8 \pm 0.6^{\mathrm{a}}$ & $10.2 \pm 1.2^{\mathrm{ab}}$ & $12.5 \pm 2.8^{\mathrm{b}}$ & $4.8 \pm 0.5^{\mathrm{a}}$ \\
\hline-0.2 & $18 \pm 2^{\mathrm{d}}$ & $3.6 \pm 0.5^{\mathrm{ab}}$ & $10.8 \pm 1.8^{\mathrm{ab}}$ & $7 \pm 1.3^{c}$ & $6.8 \pm 1.2^{\mathrm{bc}}$ \\
\hline-0.5 & $10 \pm 4^{\mathrm{de}}$ & $5.6 \pm 1.2^{\mathrm{b}}$ & $11.4 \pm 1.5^{\mathrm{ab}}$ & $3.7 \pm 2^{c}$ & $7.2 \pm 0.8^{c}$ \\
\hline-1 & $0^{\mathrm{e}}$ & - & - & - & - \\
\hline$F$ value & 83.56 & 5.78 & 3.12 & 49.89 & 13.45 \\
\hline \multicolumn{6}{|c|}{ Thymus fontanesii } \\
\hline 0 & $90 \pm 5^{\mathrm{a}}$ & $2 \pm 0^{\mathrm{a}}$ & $9.7 \pm 0.5^{\mathrm{ab}}$ & $38.1 \pm 1.6^{\mathrm{a}}$ & $4.6 \pm 0.2^{\mathrm{a}}$ \\
\hline-0.03 & $83 \pm 10^{\mathrm{a}}$ & $2 \pm 0^{\mathrm{a}}$ & $8.4 \pm 0.4^{\mathrm{a}}$ & $36.4 \pm 2.5^{\mathrm{a}}$ & $4.4 \pm 0.2^{\mathrm{a}}$ \\
\hline-0.07 & $80 \pm 9^{a}$ & $2 \pm 0^{\mathrm{a}}$ & $11.4 \pm 0.8^{\mathrm{bc}}$ & $32.6 \pm 3.3^{b}$ & $5.6 \pm 0.6^{\mathrm{ab}}$ \\
\hline-0.2 & $73 \pm 10^{\mathrm{a}}$ & $2 \pm 0^{\mathrm{a}}$ & $11.6 \pm 1^{\mathrm{bc}}$ & $32.1 \pm 1.8^{\mathrm{b}}$ & $6.1 \pm 0.5^{\mathrm{bc}}$ \\
\hline-0.5 & $50 \pm 4^{\mathrm{b}}$ & $2 \pm 0^{\mathrm{a}}$ & $11.9 \pm 0.8^{\mathrm{abc}}$ & $22 \pm 1.8^{c}$ & $6.7 \pm 0.4^{\mathrm{c}}$ \\
\hline-1 & $37 \pm 7^{b}$ & $3.4 \pm 1.2^{\mathrm{b}}$ & $12 \pm 1.2^{\mathrm{bc}}$ & $14.8 \pm 5^{\mathrm{c}}$ & $7.4 \pm 0.6^{\mathrm{cd}}$ \\
\hline-1.6 & $0^{\mathrm{d}}$ & - & - & - & - \\
\hline$F$ value & 48.69 & 4.00 & 8.96 & 23.80 & 16.83 \\
\hline
\end{tabular}

Different lower case letters (column) show significant differences between the means $(\mathrm{P}<0.05)$ according to a paired- samples $t$-test (Tukey test).

ripe seeds fail to germinate immediately after dispersal, with ungerminated seeds usually leading to the formation of transient soil seed banks germinating naturally from autumn to early spring. However, the global change impacts on the Mediterranean climate indice more frequent and longer harsh drought periods, high temperatures and changes in precipitation patterns (REY et al., 2011). This all is a threat for the plant establishment and growth. Indeed, the germination requires an availability of a resource, an optimum range of temperature and an appropriate soil moisture content. The germination success of $S$. incana, $S$. ocymastrum and $T$. fontanesii was severely deteriorated by water stress. This indicates that the drought, in the natural habitats of these species would prevent and even restrict their distribution and exploitation as medicinal plants.

Interestingly, small seeds of $T$. fontanesii were more tolerant to water stress and germinated up to $-1 \mathrm{MPa}$. However, for large seeds of S. incana and S. ocymastrum germination dramatically decreased at $-0.5 \mathrm{MPa}$. Small seed size is often described as a common adaptive feature of the plants inhabiting disturbed environments (Stromberg and Boudell, 2013). On the one hand, it may facilitate dispersal and reduce the chances of seed predation (SHEPHERD et al., 2005). On the other hand, small seeds hosting small embryos, characterized by high and fast germination, require little amounts of energy while low water potential can usually trigger germination through the degradation of storage reserves involved in the embryo growth.

In conclusion, these results will certainly be embedded in in situ consevation program upon the studied species. Considering the confirmed negative effects of water stress, we recommend sowing seeds and planting seedlings in habitats with sufficient annual precipitation amounts mitigating the impacts of drought and increasing the chance of seedling survival. In addition, to extrapolate these findings, it is more suitable to pursue this work by evaluating, in laboratory and in field, the effects of temperature, water stress and salinity on further plant growth stages. Another interesting research approach to explore in plant conservation biology is assessment of the longevity in seeds stored-under environmentally controlled conditions, carried out at regular time intervals.

\section{Acknowledgements}

The authors would like to express their thanks to the Ministry of Higher Education and Scientific Research, 

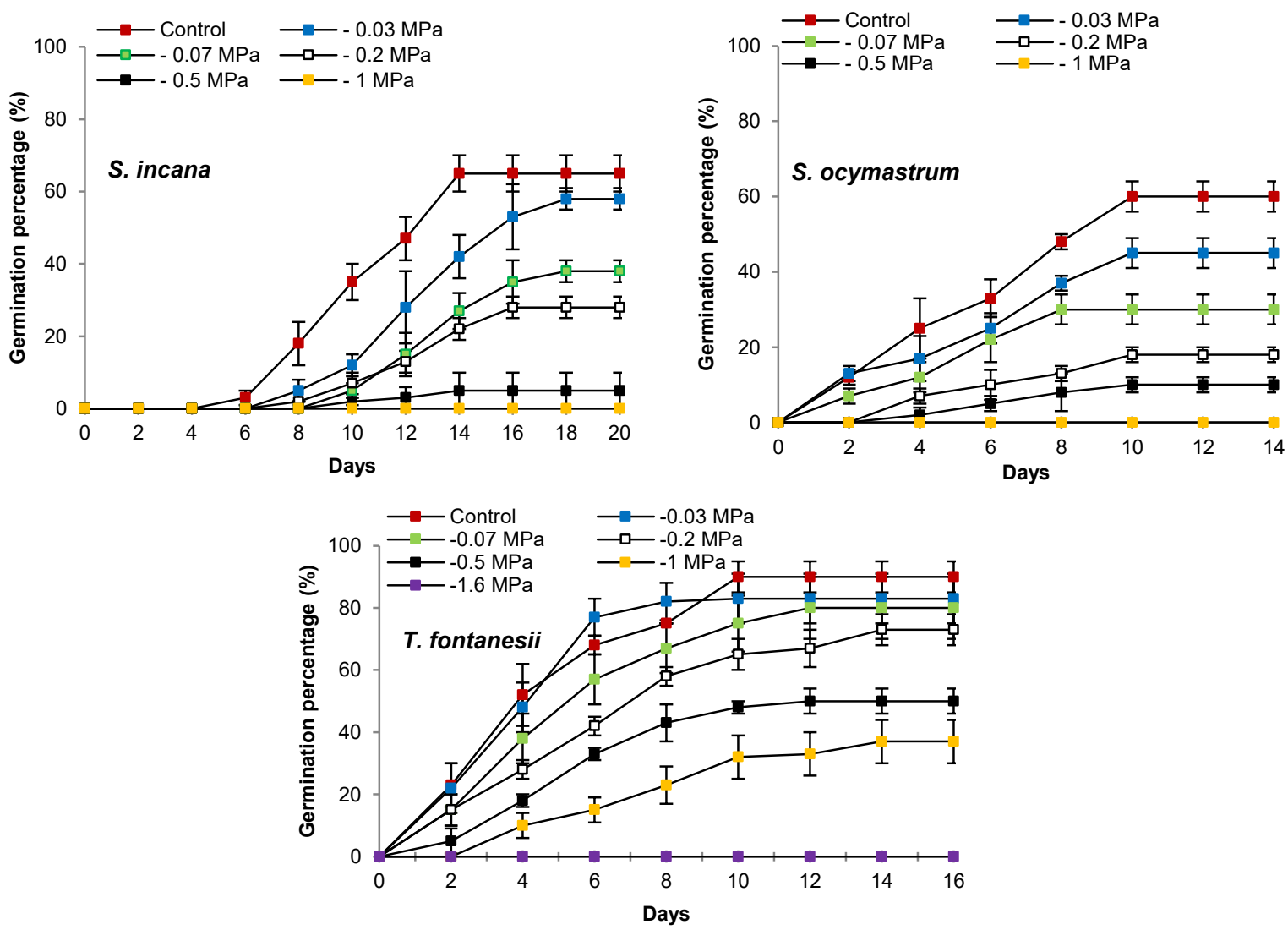

Fig. 2. Mean germination percentages (GP) as a function of time of S. incana, S. ocymastrum and T. fontanesii seeds treated with different $\mathrm{PEG}_{6000}$ concentrations. Bars represent $\pm \mathrm{SE}(\mathrm{n}=4)$.

Algeria, for providing support for this research. We sincerely appreciate both the Editor and the anonymous reviewers for their valuable comments.

\section{References}

Abbad, A., Belaqziz, R., Bekkouche, K., Markou, M., 2011. Influence of temperature and water potential on laboratory germination of two Moroccan endemic thymes: Thymus maroccanus Ball. and Thymus broussonetii Boiss. African Journal of Agricultural Research, 6: 4740-4745. doi: 10.5897/AJAR10.574

Al-Taisan, W.A., Al-Qarawi, A.A., Alsubiee, M.S., 2010 Effect of water stress by Polyethylene Glycol 8000 and Sodium Chloride on germination of Ephedra alata Decne seeds. Saudi Journal of Biological Sciences, 17: 253-257. https://doi.org/10.1016/j.sjbs.2010.04.011

BLum, A., 2015. Stress, strain, signalling, and adaptation not just a matter of definition. Journal of Experimental Botany, 67: 562-565. https://doi.org/10.1093/jxb/erv497

Calonje, M., Kay, J., Griffith, M.P., 2011. Propagation of cycad collections from seed. Applied reproductive biology for conservation. Sibbaldia, 9: 77-96. https://doi. org/10.23823/Sibbaldia/2011.123

Cheurfa, M., Allem, R., Sebainia, M., Belhireche, S., 2013. Effet de l'huile essentielle de Thymus vulgaris sur les bactéries pathogènes responsables de gastroentérites (Effect of essential oil of Thymus vulgaris on bacterial pathogens responsible for gastroenteritis). Phytothérapie, 11: 154. https://doi.org/10.1007/s10298-013-0777-7

Cochrane, J.A., Hoyl, G.L., Yates, C.J., Wood, J., Nicotra, A.B., 2015. Climate warming delays and decreases seedling emergence in a Mediterranean ecosystem. Oikos, 124: 150-160. https://doi.org/10.1111/oik.01359

DadaCh, M., Mehdadi, Z., 2018a. How short-term storage affects seed germination feature of three mediterranean medicinal plants. Journal of Biology and Nature, 9 (4): $127-135$

Dadach, M., Mehdadi, Z., 2018b. Germination responses of Ballota hirsuta seeds under conditions of temperature, salinity and water stress. Hellenic Plant Protection Journal, 11: 34-39. https://doi.org/10.2478/hppj-20180004

DadaCh, M., Mehdadi, Z., Adjouj, A., 2018. Evaluation of the tolerance to temperature and salinity on seed germination of three Lamiacea from Algerian Scrubland. Advanced Research in Life Sciences, 2 (1): 11-15. https:// doi.org/10.1515/arls-2018-0021

Dadach, M., Mehdadi, Z., Latreche, A., 2015. Effect of water stress on seed germination of Thymus serpyllum $\mathrm{L}$. from Tessala mount. Journal of Plant Sciences, 10 (4): 151-158. doi: 10.3923/jps.2015.151.158

Donohue, K., Rubio de Casas, R., Burghardt, L., Kovach, K., WiLlis, C.G., 2010. Germination, postgermination 
adaptation, and species ecological ranges. Annual Review of Ecology, Evolution, and Systematics, 41: 293-319. https://doi.org/10.1146/annurev-ecolsys-102209-144715

Faisal, S., Mujtaba, S.M., Манвоов, A.W., 2019. Polyethylene Glycol mediated osmotic stress impacts on growth and biochemical aspects of wheat (Triticum aestivum L.). Journal of Crop Science and Biotechnology, 22 (3): 213-223. https://doi.org/10.1007/s12892-0180166-0

Fernandez-Calzado, M.R., Mesa, M.J., Merzouki, A., Porcel, C.M., 2012. Vascular plant diversity and climate change in the upper zone of Sierra Nevada, Spain. Plant Biosystems, 146: 1044-1053. https://doi.org/10.1080/112 63504.2012.710273

Galmés, J., Medrano, H., Flexas, J., 2006. Germination capacity and temperature dependence in Mediterranean species of the Balearic Islands. Investigación Agraria, Sistemas y Recursos Forestales, 15: 88-95. doi: 10.5424/ srf/2006151-00955

Gill, P.K., Sharma, A.D., Singh, P., Bhullar, S.S., 2003. Changes in germination, growth and soluble sugar contents of Sorghum bicolor (L.) Moench seeds under various abiotic stresses. Plant Growth Regulation, 40: 157-162. https://doi.org/10.1023/A:1024252222376

Gorai, M., El Aloui, W., Yang, X., Neffati, M., 2014. Toward understanding the ecological role of mucilage in seed germination of a desert shrub Henophyton deserti: interactive effects of temperature, salinity and osmotic stress. Plant and Soil, 374: 727-738. https://doi. org/10.1007/s11104-013-1920-9

Khan, M.A., Ungar, I.A., 1984. The effect of salinity and temperature on the germination of polymorphic seeds and growth of Atriplex triangularis Willd. American Journal of Botany, 71 (4): 481-489. doi: 10.2307/2443323

Krichen, K., Ben Mariem, H., Chaieb, M., 2014. Ecophysiological requirements on seed germination of a Mediterranean perennial grass (Stipa tenacissima L.) under controlled temperatures and water stress. South African Journal of Botany, 94: 210-217. https://doi. org/10.1016/j.sajb.2014.07.008
Lakhal, H., Boudiar, T., Kabouche, A.S., Laggoune, A., Kabouche, Z., Topcu, G., 2011. Antioxidant activity and flavonoids of Stachys ocymastrum. Chemistry of Natural Compounds, 46: 964-965. https://doi.org/10.1007/ s10600-011-9797-4

Medail, F., Quezel, P., 1997. Hot-spots analysis for conservation of plant biodiversity in the Mediterranean basin. Annals of the Missouri Botanical Garden, 84: 112-127.

Pavia, I., Rocha, L., Moutinho-Pereira, J., Lima-Brito, J., Carlos Correia, C., 2019. Screening for drought resistance during germination of modern and old Iberian wheat cultivars. Acta Botanica Croatica, 78 (2): 169-174. doi: 10.2478/botcro-2019-0012

Ranal, M.A., Santana, D.G., 2006. How and why to measure the germination process. Revista Brasileira de Botânica, 29: 1-11. http://dx.doi.org/10.1590/S010084042006000100002

Rey, A., Pegoraro, E., Oyonarte, C., Were, A., Escribano, P., Raimundo, J., 2011. Impact of land degradation on soil respiration in a steppe (Stipa tenacissima L.) semiarid ecosystem in the SE of Spain. Soil Biology and Biochemistry, 43: 393-403. https://doi.org/10.1016/j. soilbio.2010.11.007

ShePherd, K.A., Macfarlane, T.D., Colmer, T.D., 2005. Morphology, anatomy and histochemistry of Salicornioideae (Chenopodiaceae) fruits and seeds. Annals of Botany, 95: 917-933. https://doi.org/10.1093/ aob/mci101

Stromberg, J.C., Boudell, J.A., 2013. Floods, drought, and seed mass of riparian plant species. Journal of Arid Environments, 97: 99-107. https://doi.org/10.1016/j. jaridenv.2013.05.012

Underwood, E.C., Viers, J.H., Klausmeyer, K.R., Cox, R.L. Shaw, M.R., 2009. Threats and biodiversity in the Mediterranean Biome. Diversity and Distributions, 15 (2): 188-197. https://doi.org/10.1111/j.1472-4642. 2008.00518.x

Received April 14, 2020 Accepted August 23, 2020 